\title{
Why The U.S. Justice Department Must Act Against Moody’s Corporation
}

\author{
Daniel Cash*
}

This short note discusses the importance of the decision facing the U.S. Justice Department in the near future regarding whether or not to take action against Moody's Corp. for its actions in the lead-up to the Financial Crisis. Having already fined Standard \& Poor's a record

$\$ 1.375$ billion for defrauding investors, the Justice Department faces a much different proposition. This note establishes just some of the reasons why it is imperative that Moody's is punished, even if ultimately the punishment is less noticeable than that given to Standard \&

$$
\text { Poor's. }
$$

In February 2015 the U.S. Justice Department announced that it was to fine Standard \& Poor's a record $\$ 1.375$ billion for engaging in a 'scheme to defraud investors in structured finance products' ${ }^{1}$. Having done so, it was widely expected that Moody’s would naturally be next to be punished ${ }^{2}$, given the dynamics of the Credit Rating Industry in terms of its (arguably) duopolistic structure. However, recent accounts suggest that certain aspects of Moody's operations may hamper such efforts. In analysing this potential chain of events, this note suggests that it is perhaps even more vital that the Justice Department penalises Moody's than it was when they penalised Standard \& Poor’s; allowing Moody’s to escape punishment because of their apparently systemic approach to record-keeping would set an extraordinarily

\footnotetext{
* Lecturer in Law, Aston University (d.cash@aston.ac.uk). The views and opinions expressed in this article are those of the author and do not necessarily reflect those of Wolters Kluwer.

${ }^{1}$ United States Department of Justice 'Justice Department and State Partners Secure \$1.375 Billion Settlement with S\&P for Defrauding Investors in the Lead Up to the Financial Crisis’ [2015] http://www.justice.gov/opa/pr/justice-department-and-state-partners-secure-1375-billion-settlement-spdefrauding-investors.

${ }^{2}$ A number of outlets have reported that the DoJ's indictment of Moody's is imminent, although the original story can be traced to Timothy W Martin 'Justice Department investigating Moody’s Investors Service’ [2015] Wall Street Journal (Feb. 1).
} 
dangerous precedent and facilitate an even more rapid decline in the standards set by major credit rating agencies.

Before we assess the recent murmurings regarding the Justice Department's decision to penalise Moody’s, some context is required. The Dodd-Frank Act of 2010, in responding to the iniquities of the marketplace, stated that the credit rating agencies' operations were to be considered as commercial in nature and that they should be held to the same professional levels of accountability as registered public accounting firms or securities analysts are under the Securities Laws. However, in order to make a claim for damages a party must be able to prove that the rating agency 'knowingly or recklessly failed... to conduct a reasonable investigation of the rated security with respect to the factual elements... (and/or) to obtain reasonable verification of such factual elements' ${ }^{3}$. It is for this precise reason that during the case against Standard \& Poor's, CalPERS (the retirement fund who initiated proceedings against the agency) settled with Fitch, the third component of the 'Big Three', for incriminatory documents rather than money; the presence of proof was far more valuable the compensation. In the same vein, the fact that Standard \& Poor's maintained their internal emails for a long period contributed to this verification of wrongdoing as seen by the emails uncovered by Congress - the famous email in which it was stated that 'it could be structured by cows, and we would [still] rate it' ${ }^{4}$ is perhaps the best example of this.

So, it is clear to see that proving wrongdoing is central to the aims of the Justice Department, as dictated by the Dodd-Frank Act; but, this is where the two cases of S\&P and Moody’s

\footnotetext{
${ }^{3}$ The Dodd-Frank Wall Street Reform and Consumer Protection Act of 2010124 Stat. 1376. §933 (a)(m)(1)(B). ${ }^{4}$ United States Senate, Permanent Subcommittee on Investigations Wall Street and the Financial Crisis: Anatomy of a Financial Collapse (GPO 2011) 297.
} 
differ. The settlement between CalPERS and Moody’s in March of $2016^{5}$ suggests that incriminating evidence regarding Moody’s was also obtained within CalPERS’ settlement with Fitch, but what that may be we do not yet know. Whilst that will undoubtedly be an important aspect of the Justice Department's decision, it has been suggested recently that Moody’s policy of deleting internal emails much sooner than that of S\&P will have a negative effect on the probability of proving guilt (the actual timeframes are unclear however $)^{6}$. This lack of incontrovertible proof, like that presented in the case against S\&P, could indeed be pivotal. With the decision on whether or not to proceed still to be made, it is likely that this particular element is proving to be central to the delay, especially given the fact that CalPERS settled with Moody's in March.

Whilst this is an important issue to consider, the issue of what happens if the Justice Department decides not to penalise Moody's is of much more importance. There is a demonstrable lack of ethics and standards within the rating industry ${ }^{7}$, with the Big Three in particular playing a central role in the collapse via their gatekeeping position in the global capital marketplace. If the Justice Department does indeed conclude that the lack of incontrovertible verification of wrongdoing via emails makes the possibility of prosecution (or at least the threat of prosecution realistic) too low to proceed with the action, then the message that would send needs to be addressed. Irrespective of whether one believes that financial penalties are sufficient in this particular area of the financial sector, the intimation that to evade the requirements set forth by the Dodd-Frank Act, namely that reasonable verification of wrongdoing must be established, rating agencies should delete

\footnotetext{
${ }^{5}$ Joel Rosenblatt ‘Moody’s Settles CalPERS Ratings Lawsuit for \$130 Million’ [2016] Bloomberg (Mar. 9).

${ }^{6}$ David McLaughlin, Tom Schoenberg, and Andrew M Harris ‘Moody’s Fate in Subprime Probe to be Decided Soon by U.S.' [2016] Bloomberg (Feb. 25).

7 Theodore R Malloch and Jordan D Mamorsky The End of Ethics and a Way Back: How to Fix a Fundamentally Broken Global Financial System (John Wiley \& Sons 2013) 47.
} 
communications, will fundamentally increase their ability to transgress and fundamentally decrease the ability of regulators to punish; this sentiment should be cause for an incredible amount of concern given the centralised position of the ratings industry within the sociallyvital financial markets - we know what happens when this occurs.

It is therefore vital that the Justice Department takes some form of meaningful action, regardless of whether they believe the chances of success in prosecuting are high enough. Doing so would send the message that the regulator will not relent in punishing offenders, with the resulting impact being that agencies are forced to recognise that they cannot drop their standards to farcical levels in the near-future like they did in the run-up to Financial Crisis $^{8}$. If the Justice Department do not do this then it essentially serves as a notice to the agencies that the free-for-all is about to recommence as long as (electronic) paper trails are well concealed or deleted. Now that we are coming up to a decade since the Financial Crisis, it is fathomable that market participants are awaiting the reduction of regulators' vigilance which usually comes with the passing of economic cycles ${ }^{9}$; the decision facing the Justice Department is arguably that important - a decision to relent is arguably the trigger for the continuation, or even the exponentiation, of the attack upon society that we witnessed in 2008.

\section{Conclusion}

\footnotetext{
${ }^{8}$ A clear example of this dropping of standards in the rating industry was the widespread investment-grade ratings that were afforded to sub-par structured finance products that were comprised of loans like the NINJA mortgage loans (No Job. No Income, or Assets). For more on the agencies' involvement with this process see Whitney Tilson and Glenn Tongue More Mortgage Meltdown: 6 Ways to Profit in These Bad Times (John Wiley \& Sons 2009) 12.

${ }^{9}$ For a detailed discussion about the act of regulating in relation to economic cycles see James K Galbraith The End of Normal: The Great Crisis and the Future of Growth (Simon and Schuster 2015) 157-8.
} 
This very short note aimed to promote the issue of the Justice Department's impeding decision on whether or not to penalise Moody's for its role in the Financial Crisis. Although it seems almost obvious that if Standard \& Poor's actively engaged in a scheme to defraud investors on a large scale then Moody’s would have done so too (given the oligopolistic nature of the industry), the Dodd-Frank Act dictates that to bring a successful action against an agency one must have reasonable verification of wrongdoing. This seems entirely acceptable, but understanding the rating agencies means that it is very difficult to meet this requirement, both because of their culture (as evidenced by their recent behaviour, although it is arguable that it goes back much further than that) and also because of the oligopolistic (arguably duopolistic) industry structure. We saw how whilst the Justice Department was able to prove S\&P’s guilt by a combination of industry-insider information and evidence contained within internal emails, Moody's policies of deleting their communications much earlier than S\&P do is perhaps the reason for the delay of the Justice Department's decision. The potential effect of the Justice Department's decision is massive either way. If they choose to prosecute, irrespective of outcome, then we know that aiming to protect society from the iniquities of the marketplace is at least still, relatively, on the agenda. This is positive. However, if the Justice Department decide not to prosecute then we can consider the regulatory-fertile and regulatory-populist post-crisis era to be over. This is extraordinarily negative.

It may sound extreme or dramatic to suggest such importance, but it is hard to argue against the understanding that credit rating agencies are central to modern economic cycles. If they are under regulatory pressure they will not go all-out to facilitate destructive finance like they 
did before $2008^{10}$; however, if they even perceive that pressure to be absent, then we have historical proof of what they will do. The much larger issue, when understood on this basis, is whether society is ready for another onslaught. Has society rebounded enough to be attacked in such a systemic way again, so soon? It is contented here that it has not. Sending the message to rating agencies that regulatory pressure is diminishing is an acute hazard that we should consider, and it is hoped that the Justice Department realise this - whether or not they will remains to be seen.

${ }^{10}$ The Senate's investigation (n 4) provides an extraordinary amount of examples of this facilitation (see Chapter 5 in particular). 